\title{
Decontamination of Salmonella Typhimurium with chitosan and lactic acid on broiler carcasses
}

\author{
Zeynep KAPLAN ${ }^{1, a}$, Özen YURDAKUL ${ }^{1, b}$, Erhan KEYVAN ${ }^{1, c, ~} ₫$, Erdi ŞEN ${ }^{1, d}$ \\ ${ }^{1}$ Burdur Mehmet Akif Ersoy University, Faculty of Veterinary Medicine, Department of Food Hygiene and Technology, Burdur, \\ Turkey. \\ aORCID: 0000-0002-0252-1489; ' $\mathrm{O}$ ORCID: 0000-0001-7680-015X; 'ORCID: 0000-0002-2981-437X; \\ dORCID: 0000-0002-5140-3833.
}

\author{
${ }^{\square}$ Corresponding author: erhankeyvan@mehmetakif.edu.tr
}

Received date: 28.09.2020 - Accepted date: 21.12.2020

\begin{abstract}
Salmonella Typhimurium is frequently isolated from chicken meat. The main purpose of current study was to analyze the decontamination of $S$. Typhimurium by using different concentrations of chitosan, lactic acid and chitosan and lactic acid combination on broiler carcasses. $S$. Typhimurium was inoculated to broiler carcasses at $10^{8} \mathrm{cfu} / \mathrm{mL}$ in eight different study groups. Then, contaminated carcasses were treated with $1 \%, 2 \%$ lactic acid and $0.1 \%, 0.05 \%$ chitosan for $5,10,15$ min. Also, effects of the combination of chitosan and lactic acid $(0.05 \%$ chitosan- $1 \%$ lactic acid, $0.01 \%$ chitosan- $1 \%$ lactic acid) were analyzed for $5,10,15$ min. Carcasses samples treated with chitosan and lactic acid were analysed for survival of $S$. Typhimurium on the 0,3 and 7 days of storage time. Lactic acid $(1 \%, 2 \%)$, combination of chitosan and lactic acid $(0.05 \%$ chitosan $+1 \%$ lactic acid and $0.01 \%$ chitosan and $1 \%$ lactic acid) were detected to have antimicrobial effect on $S$. Typhimurium inoculated into carcasses $(\mathrm{P}<0.05)$. There is no difference between the working groups in terms of implementation time ( $P>0.05)$. According to the study, it was found that the combination of lactic acid and chitosan is the most effective method against $S$. Typhimurium in poultry carcasses. As a result, it is thought that the decontaminant agents which preferred in the study can be used in various applications in the poultry industry.
\end{abstract}

Keywords: Broiler carcass, Chitosan, Lactic acid, Salmonella Typhimurium.

\section{Broiler karkaslarında Salmonella Typhimurium'un kitosan ve laktik asit ile dekontaminasyonu}

Özet: Salmonella Typhimurium, tavuk etlerinden en sık izole edilen patojenden biridir. Bu çalışmada, çeşitli konsantrasyonlarda kullanılan kitosan, laktik asit, kitosan ve laktik asit kombinasyonunun $S$. Typhimurium ile kontamine olmuş etlik broyler karkaslarına etkileri araştırılmıştır. $S$. Typhimurium broiler karkaslarına $10^{8} \mathrm{kob} / \mathrm{mL}$ inokule edilerek 8 farklı grup oluşturulmuştur. Daha sonra kontamine edilen karkaslar \%1, \%2 laktik asit, \%0,05, \%0,1 kitosan, laktik asit ve kitosan kombinasyonları ile 5, 10 ve 15 dakika boyunca muamele edilmiştir. Kitosan ve laktik asit ile muamele edilmiş karkas örneklerin, 0., 3. ve 7. günlerde analizleri yapılmıştır. Karkaslara inokule edilen $S$. Typhimurium üzerine laktik asit (\%1, \%2), kitosan ve laktik asit kombinasyonunun $(\% 0,05$ kitosan $+\% 1$ laktik asit ve \%0,01 kitosan ve \%1 laktik asit) antimikrobiyal etkiye sahip olduğu tespit edilmiştir $(\mathrm{P}<0,05)$. Uygulama süresi açısından çalışma grupları arasında fark olmadığı gözlendi $(\mathrm{P}>0,05)$. Bu çalışmada, laktik asit ve kitosan kombinasyonunun kanatlı karkaslarında $S$. Typhimurium'a karşı en etkili yöntem olduğu doğrulanmıştır. Sonuç olarak çalışmada kullanılan dekontaminant ajanların kümes hayvanı endüstrisindeki çeşitli uygulamalarda kullanılabileceği düşünülmektedir.

Anahtar sözcükler: Broiler karkas, Kitosan, Laktik asit, Salmonella Typhimurium.

\section{Introduction}

Meat and meat products consumed in the diet contribute significantly to the intake of energy, protein, and micronutrients (13). Poultry meat is frequently preferred around the world because of its high protein ingredient, balance of polyunsaturated fatty acids ( $n-6, n-$ 3 ), low fat and cholesterol content, affordable price compared to red meat $(10,49)$. Therefore, poultry meat constitutes $30 \%$ of the meat consumed in the world (17).
Poultry meat is an important reservoir for pathogenic bacteria and is often associated with foodborne diseases $(9,20,21,53)$. Salmonella spp. are potential zoonotic agents that can pose a danger to society (62). Based on reported studies, Salmonella enterica serovars are among the most important foodborne pathogens (4). Among the Salmonella serotypes, $S$. Typhimurium and $S$. Enteritidis are the two most common serotypes, and $S$. Typhimurium is known as the most dominant isolated serotype 
worldwide $(23,67)$. Therefore, it is important to keep $S$. Enteritidis and $S$. Typhimurium separate from other Salmonella serotypes as they are specified in zoonosis control legislation and have differences in epidemiology $(3,32)$. Also, Salmonella spp. can infect a variety of animals such as sheep, cattle, poultry and pigs (59). Salmonella spp. can be transmitted to humans by way of contact with infected animals, polluted water and the environment. However, cases in humans are mostly via contaminated food products $(19,25)$. The consumption of poultry meat and egg are the most important source of Salmonella spp. for humans $(37,64)$.

In addition to general hygiene rules, organic chemicals are used as a decontamination fluid in the poultry and meat industry to destroy or reduce pathogenic microorganisms on the carcass surface $(7,44,45)$. Organic acids have been found to be effective in reducing foodborne pathogens such as Escherichia coli O157:H7, $S$. Typhimurium and Listeria monocytogenes on carcass surfaces $(34,57)$. Among the organic acids, lactic acid (LA) is frequently used as a decontamination agent in broiler carcasses. Many studies have been carried out on lactic acid application to control pathogenic bacteria in broiler carcasses. $(1,47,48)$.

Chitosan obtained by deacetylation of chitin is a naturally sourced polycationic biopolymer in the form of a powder that is insoluble in water, high viscosity, nontoxic, non-antigenic, soluble in organic acids $(50,66)$. Due to the various properties of chitosan, it is widely used in biotechnology, pharmacy, medicine, veterinary medicine, water treatment, textile, agriculture, cosmetics and food industries $(5,12,29,43,57)$. It has been stated in various sources that chitosan can be used as an alternative in storage foods and increasing their shelf life $(46,52)$. Chitosan is a potential protective additive for foods with its antimicrobial effect on foodborne pathogen bacteria, mold and yeast $(6,11,39)$. Chitosan can be dissolved in organic acids. Therefore, the use of chitosan alone or in combination with other organic acids is among the strategies that can be preferred in reducing the microbial load on the animal carcass surface $(14,40)$.

In the present study, antimicrobial effect of chitosan, lactic acid, chitosan and lactic acid combination used in various concentrations on broiler carcasses contaminated with $S$. Typhimurium were investigated.

\section{Materials and Methods}

Preparation of bacterial strain: The stock strain used in this study were, $S$. Typhimurium (ATCC 14028). Cultures were incubated in $10 \mathrm{~mL}$ Tryptic Soy Broth (Oxoid, UK) for at $35^{\circ} \mathrm{C}$ at $24 \mathrm{~h}$. The microbial density was set to $0.5 \mathrm{McF}$ arland turbidity standard approximately bacteria density of $10^{8} \mathrm{cfu} / \mathrm{mL}^{-1}$. The prepared strain mixture was used for broiler carcass contamination within $30 \mathrm{~min}$.

Contamination of broiler carcasses with $S$. Typhimurium: In this present study, broiler carcasses $(1.2-1.4 \mathrm{~kg})$ saled from the local market were used. A total of 144 broiler carcasses were used in the study. Except the control group each experimental group, were contaminated with $10^{8} \mathrm{cfu} / \mathrm{mL}^{-1}$ bacterial culture. The broiler carcasses were kept in bacterial culture for $30 \mathrm{~min}$ for adhesion.

Decontamination agents, groups and analysis: In the current study, chitosan (Sigma, US), lactic acid (Sigma, US) and their combinations were used. Contaminated carcasses were treated with 1\%,2\% lactic acid and $0.1 \%, 0.05 \%$ chitosan for 5, 10, $15 \mathrm{~min}$. Also, effects of the combination of chitosan and lactic acid ( $0.05 \%$ chitosan- $1 \%$ lactic acid, $0.01 \%$ chitosan- $1 \%$ lactic acid) were anaylsed with negative and positive control. The exposure times of the carcasses to decontaminant fluids were subdivided into 5, 10, $15 \mathrm{~min}$. Microbiological analyzes were performed in these groups on days 0,3 and 7. After each experiment, the carcass samples were kept in a refrigerator at $4^{\circ} \mathrm{C}$. Chemical decontaminants which used in carcass decontamination and their prepared concentrations are shown in Table 1.

Table 1. Decontamination agents and concentrations used in broiler carcasses.

\begin{tabular}{cc}
\hline Decontaminants & Concentrations \\
\hline Lactic acid & $1 \%$ and $2 \%$ \\
Chitosan solution & $0.1 \%$ and $0.05 \%$ \\
Combination of chitosan ve & $0.05 \%+1 \%$ and $0.01 \%+$ \\
lactic acid & $1 \%$ \\
\hline
\end{tabular}

Analysis procedure of broiler carcasses: Microbiological analysis of chicken carcasses decontaminated with $S$. Typhimurium were performed on days 0,3 and 7. Firstly, chicken carcasses were washed with sterile distilled water in sterile bags and rinsed with peptone water (Biolife, Italy) in order to find out whether there was Salmonella contamination. Afterwards freshly processed broiler carcasses were rinsed with decontaminant fluids, and the rinses were serially diluted 10 -fold with $0.1 \%$ peptone water. The samples were then spread on xylose lysine deoxycholate agar (XLD) (Merck, Germany) and brilliant-green phenol-red lactose sucrose (BPLS) agar (Merck, Germany) by spread plate technique $(0.1 \mathrm{ml})$. After incubation, $1-2.5 \mathrm{~mm}$ in diameter, central black periphery red colonies in XLD agar and 1-1.5 mm in diameter, pink red colonies were considered as Salmonella suspects. Suspicious colonies were inoculated into triple sugar iron (TSI) (Merck, Germany) agar and 
lysine iron agar (LIA) (Merck, Germany) at $37^{\circ} \mathrm{C}$ for overnight. In the end, serologically colonies with suspected Salmonella spp. were confirmed by testing with Salmonella antiserum (Difco 2264-47-2, US) (18).

Statistical analysis: The obtained data were statistically evaluated by the use of SPSS 25 statistical package. The variables were expressed as mean \pm standard deviation and median (Maximum-Minimum) percentage and frequency values. The suitability of the data to the analysis of variance in the factorial order was evaluated with the multivariate normal distribution and Box-M Test of Homogeneity of Variances. Means were compared by a factorial analyese of variance. Parametric tests (analysis of variance in factorial order) that did not meet the prerequisites, the data were reevaluated by box cox data transformation and the obtained data were processed by analysis of variance in factorial order. Corrected LSD Test was used for Multiple comparisons. The significance level was expressed as $\mathrm{P}<0.05$.

\section{Results}

Negative and Positive Control Group Results: In this study, Salmonella negative broiler carcasses were used. In the positive control group, contaminated broiler carcasses with $S$. Typhimurium were determined as 6.60, 6.81 , and $6.88 \log \mathrm{cfu} / \mathrm{mL}$ on days $0,3,7$, respectively. The negative control group results were detected as negative for the presence of Salmonella.

Effects of lactic acid (1\% and 2\%) application to broiler carcasses: Based on our results, compared with the control group, it was observed that the count of $S$. Typhimurium was $4.16,4.35,4.77 \log \mathrm{cfu} / \mathrm{mL}$ at $5,10,15$ min on day $0 ; 5.94,4.42,4.27 \log \mathrm{cfu} / \mathrm{mL}$ at $5,10,15 \mathrm{~min}$ on day $3 ; 6.22,5.83,4.12 \log \mathrm{cfu} / \mathrm{mL}$ at $5,10,15 \mathrm{~min}$ on day 7, respectively. The reduction levels of $S$. Typhimurium were determined as $2.44,2.25,1.83 \mathrm{log}$ $\mathrm{cfu} / \mathrm{mL}$ at $5,10,15 \mathrm{~min}$ on day $0,0.87,2.39,2.54 \mathrm{log}$ $\mathrm{cfu} / \mathrm{mL}$ at $5,10,15 \mathrm{~min}$ on day $3,0.66,1.05,2.76 \mathrm{log}$ $\mathrm{cfu} / \mathrm{mL}$ at $5,10,15 \mathrm{~min}$ on day 7 , respectively.

In the experimental groups containing $2 \%$ lactic acid, the count of $S$. Typhimurium was found $4.05,3.82,3.45$ $\log \mathrm{cfu} / \mathrm{mL}$ at $5,10,15 \mathrm{~min}$ on day $0 ; 3.90,3.67,3.33 \log$ $\mathrm{cfu} / \mathrm{mL}$ at $5,10,15 \mathrm{~min}$ on day $3 ; 3.60,3.93,3.43 \mathrm{log}$ $\mathrm{cfu} / \mathrm{mL}$ at $5,10,15 \mathrm{~min}$ on day 7 , respectively. The reduction levels of $S$. Typhimurium were observed as 2.55, 2.78, 3.15 $\log \mathrm{cfu} / \mathrm{mL}$ at $5,10,15 \mathrm{~min}$ on day $0 ; 2.91$, $3.14,3.48 \log \mathrm{cfu} / \mathrm{mL}$ at $5,10,15 \mathrm{~min}$ on day $3 ; 3.28,2.95$, $3.45 \log \mathrm{cfu} / \mathrm{mL}$ at $5,10,15 \mathrm{~min}$ on day 7 , respectively. In accordance with the results of the statistical analysis, it was observed that there was a significant difference between all groups compared to the control group $(\mathrm{P}<0.05)$, but there was no significant difference between them according to the application times.

Effects of Chitosan (0.05\% and 0.1\%) application to broiler carcasses: The decrease in the levels of $0.05 \%$ and $0.1 \%$ chitosan applications of $S$. Typhimurium in 5 min, $10 \mathrm{~min}$ and $15 \mathrm{~min}$ in comparison with the positive control is shown in Table 2 .

Effects of lactic acid and chitosan combinations application to broiler carcasses: The results of $S$. Typhimurium of the experimental groups with the control group containing $0.01 \%$ chitosan, $1 \%$ lactic acid and $0.05 \%$ chitosan and $1 \%$ lactic acid combination solution are given in Table 3 .

Table 2. Effects of $0.05 \%$ and $0.1 \%$ chitosan on $S$. Typhimurium.

\begin{tabular}{cccccccccc}
\hline $\begin{array}{c}\text { Concentration of } \\
\text { chitosan }\end{array}$ & \multicolumn{3}{c}{ S. Typhimurium counts $(\log \mathbf{c f u} / \mathbf{m L})$} \\
\hline & Day 0 & Day 3 & Day 7 & Day 0 & Day 3 & Day 7 & Day 0 & Day 3 & Day 7 \\
$0.05 \%$ & 6.53 & 6.46 & 7.32 & 6.29 & 6.22 & 6.3 & 6.57 & 6.74 & 6.05 \\
$0.1 \%$ & 6.31 & 4.44 & 6.52 & 6.44 & 6.42 & 6.74 & 6.43 & 6.38 & 6.47 \\
\hline
\end{tabular}

Table 3. Effects of Lactic Acid and Chitosan Combinations on S. Typhimurium.

\begin{tabular}{|c|c|c|c|c|c|c|c|c|c|}
\hline \multirow{3}{*}{$\begin{array}{l}\text { Concentration of lactic } \\
\text { acid and chitosan } \\
\text { combinations }\end{array}$} & \multicolumn{9}{|c|}{ S. Typhimurium counts $(\log \mathrm{cfu} / \mathrm{mL})$} \\
\hline & \multicolumn{3}{|c|}{$5 \mathrm{~min}$} & \multicolumn{4}{|c|}{$10 \mathrm{~min}$} & \multicolumn{2}{|l|}{$15 \mathrm{~min}$} \\
\hline & Day 0 & Day 3 & Day 7 & Day 0 & Day 3 & Day 7 & Day 0 & Day 3 & Day 7 \\
\hline $\begin{array}{c}0.01 \% \text { chitosan and } 1 \% \\
\text { lactic acid }\end{array}$ & 1.99 & 4.82 & 1.99 & 1.99 & 3.14 & 3.53 & 1.96 & 3.78 & 1.99 \\
\hline $\begin{array}{c}0.05 \% \text { chitosan and } 1 \% \\
\text { lactic acid }\end{array}$ & 1.99 & 5.38 & 6.17 & 1.99 & 6.17 & 6.16 & 1.99 & 3.93 & 6.12 \\
\hline
\end{tabular}




\section{Discussion and Conclusion}

Poultry meat is a significant reservoir for Salmonella spp. (22). The main reason for the occurrence of foodborne salmonellosis in humans originate from contaminated chicken meat consumption $(2,16)$. Causes of Salmonella spp. contamination of poultry meat include slaughtering Salmonella-positive flocks in the slaughterhouse, the slaughter equipment, scalding, plucking, evisceration, and cross contamination and lack of personal hygiene $(8,51)$. Salmonella species are most common in fresh broiler meat among the various meat and meat product categories (pork, turkey, beef and ready-toeat foods prepared from these meats and ground beef) (15). According to the previous studies, one of the predominant serotypes in chicken meat is $S$. Typhimurium $(31,61,65)$. It has been assigned as a result of the studies that this situation creates an important potential for public health.

Despite the application of many preservation methods, foodborne infections still cannot be completely prevented. Accordingly, various decontamination methods are used to reduce or completely eliminate the number of pathogenic microorganisms in broiler carcasses to be consumed. Various chemicals are used for decontamination and organic acids take an important place among them (58). Organic acids used as decontamination liquids are frequently applied to the surfaces of various meats and carcasses. Organic acid applications are cheap, simple, fast and effective (24). Among the organic acids, acetic acid and lactic acid have been the most commonly accepted carcass decontaminant fluids (58). Bactericidal or bacteriostatic effect can be obtained on the carcass surface with various organic acids by spraying or dipping on the carcass (55). In addition, the use of organic acids is generally recognized as safe (GRAS) for meat and poultry products by the U.S. Food and Drug Administration (38). The researchers reported that the effect of lactic acid on bacteria was related to the concentration of lactic acid used, the temperature of the lactic acid solution, the method of application, the processing time and the $\mathrm{pH}$ value $(54,57)$. The use of natural substances such as chitosan together with organic acids for decontamination is increasing day by day. In this study, the inhibitory effects of lactic acid, chitosan, and combinations of chitosan with lactic acid at different doses, different times and different storage days on $S$. Typhimurium were examined. The efficacy and antimicrobial effects of lactic acid in poultry have been studied in many studies. Xiong et al. (63) found that $1 \%$ and $2 \%$ LA sprayed on chicken skin at room temperature for $30 \mathrm{~s}$ reduced $S$. Typhimurium counts by $2.2 \log \mathrm{cfu} / \mathrm{mL}$. In a similar study, Li et al. (33) applied 1\% lactic acid to chicken carcasses contaminated with $S$. Typhimurium by spraying method for $90 \mathrm{~s}$. As a result of the application, a unit reduction of $1.6 \log \mathrm{cfu} / \mathrm{mL}$ was observed. In one study, as a result of the treatment of $S$. Typhimurium with $1 \%$ and $2 \%$ lactic acid for $3 \mathrm{~min}$, a decrease of $1 \log$ and $3.3 \log \mathrm{cfu} / \mathrm{cm}^{2}$ was observed in the count of microorganisms, respectively (41). Mulder et al. (45), in their study on $S$. Typhimurium inoculated into chicken carcasses, they used $0.5 \%$ and $1 \%$ lactic acid in dipping water at room temperature for $10 \mathrm{~min}$. The result of the application, 1-2 log cfu/mL reduction was detected. In other studies, it has been observed that varying amounts of lactic acid are quite effective on $S$. Typhimurium (28, $36,57)$. This study investigated the effect of $1 \%$ and $2 \%$ lactic acid against $S$. Typhimurium in chicken carcasses. The most effective method in this study was obtained in $2 \%$ lactic acid applications for $15 \mathrm{~min}$. According to other studies, the results are similar despite the differences in concentration and application time.

Chitosan which does not show toxic effects, is very effective against foodborne pathogens with its antibacterial and antifungal effects (60). Although the antimicrobial effect of chitosan is not known exactly, it may change the structure of the cytoplasmic membrane due to its cationic feature (42). Moreover, chitosan may bind to DNA and inhibit RNA synthesis (35). The antimicrobial effect of chitosan depends on the type of microorganism, properties of chitosan, physical form of chitosan and environmental factors (30). There are few studies on the effect of chitosan against Salmonella spp. in poultry $(14,39,40)$. The effect of chitosan on Salmonella spp. and $S$. Typhimurium in broiler chickens was investigated by using it alone or in combination with organic acids. In the study conducted by El-Khawas et al. (14), the effect of chitosan $(0.5 \%, 1 \%, 2 \%)$, lactic acid (1\%) and combinations of lactic acid (1\%) and chitosan ( $2 \%$ ) on $S$. Typhimurium was investigated in chicken fillets cooled at $4{ }^{\circ} \mathrm{C}$. As a result, they found that the effect of chitosan $2 \%$, lactic acid $1 \%$ and chitosan-lactic acid combination applications were approximately $1.5 \mathrm{log}$ $\mathrm{cfu} / \mathrm{mL}$ reduction. When the study and our results are compared, the effect of lactic acid is in line with our results; however, it was observed that the effect of chitosan was higher than in our study. The reason for this is thought to be due to the concentration used and the solvent differences. In this study, it was concluded that dissolving chitosan with distilled water reduces its effectiveness. In one study, skin samples were dipped into solution containing $10^{6} \mathrm{cfu} / \mathrm{mL}$ of $S$. Typhimurium for 30 s. Afterwards, skin samples dipped into a solution containing $0.5 \%$ chitosan for $30 \mathrm{~s}$. Chitosan has been seen to reduce the number of $S$. Typhimurium after 24 hours (40). When compared with our results, it is seen that the results are parallel according to the applications of chitosan at different densities, different solvents and times. Based on the results, it was observed that the combination of chitosan and lactic acid at different 
concentrations made a significant difference compared to the control group. However, it was found that the difference between two different chitosan and lactic acid combination $(0.05 \%+1 \%$ and $0.01 \%+1 \%)$ applications and the application times ( $5 \mathrm{~min}, 10 \mathrm{~min}, 15 \mathrm{~min}$ ) was not significant. In a different study, it has been reported that by adding chitosan to the diet of broiler chickens for 7 days, it significantly reduces the rate of $S$. Typhimurium (39). According to the researches, it has been understood that taking derivatives such as chitosan and oligochitosan with diet has a prebiotic effect and supports the growth of beneficial bacteria and helps regulate the immune system $(26,27)$.

Poultry meat is an important food due to its nutritious properties and economic advantage compared to red meat in Turkey. However, depending on the cutting process, hygienic conditions cannot be fully provided. Consumption of broiler carcasses contaminated with $S$. Typhimurium can pose a danger to human health as well as adversely affect the poultry industry. Therefore, the use of food preservation methods to reduce or eliminate the microorganism count is important in broiler carcasses. The antimicrobial effects of organic acids and chitosan can be used when hygiene practices are inadequate to reduce microbial contamination in broiler carcasses. According to our results, it was found that the combinations of lactic acid and chitosan $(0.05 \%$ chitosan $+1 \%$ lactic acid and $0.01 \%$ chitosan and $1 \%$ lactic acid) are the most effective method against $S$. Typhimurium in poultry carcasses. The combination of chitosan with lactic acid can be effective for use as a decontamination solution in broiler carcasses. The decontaminants used in the study can be used in the poultry industry to reduce the number of microorganisms and increase the shelf life of the products.

\section{Acknowledgment}

This study includes data of the first author's Master thesis.

\section{Financial Support}

This research received no grant from any funding agency/sector.

\section{Ethical Statement}

This study does not present any ethical concerns.

\section{Conflict of Interest}

The authors declared that there is no conflict of interest.

\section{References}

1. Agırdemır O, Yurdakul O, Keyvan E, et al (2020): Effects of various chemical decontaminants on Salmonella
Typhimurium survival in chicken carcasses. Food Sci Technol (Campinas).

2. Allerberger F (2016): Poultry and human infections. Clin Microbiol Infect, 22, 101-102.

3. Anonymus (2014): Salmonella ve Belirlenmiş Diğer Gıda Kaynaklı Zoonotik Etkenlerin Kontrol Altına Alınması Hakkında Yönetmelik. Avalaible at: https://www.resmigazete.gov.tr/eskiler/2014/03/20140327. pdf. (Accessed Sept 24, 2020).

4. Antunes P, Mourão J, Campos J, et al (2016): Salmonellosis: the role of poultry meat. Clin Microbiol Infect, 22, 110-121.

5. Aranaz I, Acosta N, Civera C, et al (2018): Cosmetics and cosmeceutical applications of chitin, chitosan and their derivatives. Polymers, 10, 213.

6. Bhoir SA, Jhaveri M, Chawla SP (2019): Evaluation and predictive modeling of the effect of chitosan and gamma irradiation on quality of stored chilled chicken meat. J Food Process Eng, 42, e13254.

7. Bolder NM (1997): Decontamination of meat and poultry carcasses. Trends Food Sci Technol, 8, 221-227.

8. Cardinale E, Tall F, Cisse M, et al (2005): Risk factors associated with Salmonella enterica subsp. enterica contamination of chicken carcases in Senegal. Br Poult Sci, 46, 293-299.

9. Castañeda-Gulla K, Sattlegger E, Mutukumira AN (2020): Persistent contamination of Salmonella, Campylobacter, Escherichia coli, and Staphylococcus aureus at a broiler farm in New Zealand. Can J Microbiol, 66, 171-185.

10. Cavani C, Petracci M, Trocino A, et al (2009): Advances in research on poultry and rabbit meat quality. Ital J Anim Sci, 8, 741-750.

11. Chang SH, Chen CH, Tsai GJ (2020): Effects of chitosan on Clostridium perfringens and application in the preservation of pork sausage. Mar Drugs, 18, 70.

12. Cheung RCF, Ng TB, Wong JH, et al (2015): Chitosan: an update on potential biomedical and pharmaceutical applications. Mar Drugs, 13, 5156-5186.

13. De Smet S, Vossen E (2016): Meat: The balance between nutrition and health. A review. Meat Sci, 120, 145-156.

14. El-Khawas KM, Mashat BH, Attala OA, et al (2020): Control of Salmonella and Escherichia coli in chilled chicken fillets using chitosan and lactic acid. CYTA J Food, 18, 445-450.

15. European Food Safety Authority and European Centre for Disease Prevention and Control-EFSA/ECDC (2018): The European Union summary report on trends and sources of zoonoses, zoonotic agents and food-borne outbreaks in 2017. EFSA Journal, 16, e05500.

16. Foley SL, Nayak R, Hanning IB (2011): Population dynamics of Salmonella enterica serotypes in commercial egg and poultry production. Appl Environ Microbiol, 77, 4273-4279.

17. Food and Agriculture Organization-FAO (2006): Databases: Food Balance Sheets. Avalaible at: http://faostat.fao.org. (Accessed Sept 24, 2020).

18. Food and Agriculture Organization-FAO (2016): Bacteriological Analytical Manual, Chapter 5 Salmonella. 
Avalaible at: http://www.fda.gov/Food/FoodScienceResearch/LaboratoryMethods/ucm070149.html. (Accessed Sept 24, 2020).

19. Firouzabadi A, Saadati D, Najimi M, et al (2020): Prevalence and related factors of Salmonella spp. and Salmonella Typhimurium contamination among broiler farms in Kerman province, Iran. Prev Vet Med, 175, 104838.

20. Goncuoglu M, Ormanci FSB, Uludag M, et al (2016): Prevalence and antibiotic resistance of Salmonella spp. and Salmonella Typhimurium in broiler carcasses wings and liver. J Food Saf, 36, 524-531.

21. Gücükoğlu A, Çadırcı Ö, Gülel GT (2020): Serotyping and antibiotic resistance profile of Listeria monocytogenes isolated from organic chicken meat. Kafkas Univ Vet Fak Derg, 26, 499-505.

22. Heredia N, García S (2018): Animals as sources of foodborne pathogens: A review. Anim Nutr, 4, 250-255.

23. Herikstad H, Motarjemi Y, Tauxe RV (2002): Salmonella surveillance: a global survey of public health serotyping. Epidemiol Infect, 129, 1-8.

24. Hinton MH, Corry JEL (1999): The decontamination of carcass meat. 285-296. In: R Richardson (Ed), Poultry Meat Science. Oxon, Cabi Publishing.

25. Hoelzer K, Switt AIM, Wiedmann M (2011): Animal contact as a source of human non-typhoidal salmonellosis. Vet Res, 42, 34.

26. Huang RL, Yin YL, Wu GY, et al (2005): Effect of dietary oligochitosan supplementation on ileal digestibility of nutrients and performance in broilers. Poult Sci, 84, 13831388

27. Huang RL, Deng ZY, Yang C et al (2007): Dietary oligochitosan supplementation enhances immune status of broilers. J Sci Food Agric, 87, 153-159.

28. Hwang C, Beuchat LR (1995): Efficacy of selected chemicals for killing pathogenic and spoilage microorganisms on chicken skin. J Food Prot, 58, 19-23.

29. Kabanov VL, Novinyuk LV (2020): Chitosan application in food technology: A review of rescent advances. Food Systems, 3, 10-15.

30. Kong M, Chen XG, Xing K (2010): Antimicrobial properties of chitosan and mode of action: a state of the art review. Int J Food Microbiol, 144, 51-63.

31. Kuang X, Hao H, Dai M (2015): Serotypes and antimicrobial susceptibility of Salmonella spp. isolated from farm animals in China. Front Microbiol, 6, 1-11.

32. Lim YH, Hirose K, Izumiya H, et al (2003): Multiplex polymerase chain reaction assay for selective detection of Salmonella enterica serovar Typhimurium. Jpn J Infect Dis, 56, 151-155.

33. Li Y, Slavik MF, Walker JT, et al (1997): Pre-chill spray of chicken carcasses to reduce Salmonella Typhimurium. J Food Sci, 62, 605-607.

34. Loretz M, Stephan R, Zweifel C (2010): Antimicrobial activity of decontamination treatments for poultry carcasses: a literature survey. Food Control, 21, 791-804.

35. Luo Y, Wang Q (2013): Recent advances of chitosan and its derivatives for novel applications in food science. J Food Process \& Bev, 1, 1-13.

36. Madushanka DNN, Jayaweera TSP, Jayasinghe JMCS et al (2018): Decontaminating effect of organic acids and natural compounds on broiler chicken meat contaminated with Salmonella Typhimurium. Asian Food Sci J, 3, 1-9.

37. Magdy OS, Moussa IM, Hussein HA, et al (2020): Genetic diversity of Salmonella enterica recovered from chickens farms and its potential transmission to human. $\mathrm{J}$ Infect Public Health, 13, 571-576.

38. Mani-López E, García HS, López-Malo A (2012): Organic acids as antimicrobials to control Salmonella in meat and poultry products. Food Res Int, 45, 713-721.

39. Menconi, A., Pumford, N. R., Morgan, et al (2014): Effect of chitosan on Salmonella Typhimurium in broiler chickens. Foodborne Pathog Dis, 11, 165-169.

40. Menconi A, Hernandez-Velasco X, Latorre JD et al (2013): Effect of chitosan as a biological sanitizer for Salmonella Typhimurium and aerobic gram negative spoilage bacteria present on chicken skin. Int J Poult Sci, 12, 318-321.

41. Mohamed HM, Abdel-Naeem HH (2018): Enhancing the bactericidal efficacy of lactic acid against Salmonella typhimurium attached to chicken skin by sodium dodecyl sulphate addition. LWT-Food Sci Technol, 87, 464-469.

42. Moradi M, Tajik H, No HK, et al (2010): Potential inherent properties of chitosan and its applications in preserving muscle food. J Chitin Chitosan, 15, 35-45.

43. Morin-Crini N, Lichtfouse E, Torri G et al (2019): Applications of chitosan in food, pharmaceuticals, medicine, cosmetics, agriculture, textiles, pulp and paper, biotechnology, and environmental chemistry. Environ Chem Lett, 17, 1667-1692.

44. Morshedy AEMA, Sallam KI (2009): Improving the microbial quality and shelf life of chicken carcasses by trisodium phosphate and lactic acid dipping. Int J Poult Sci, 8, 645-650.

45. Mulder RWAW, Van der Hulst MC, Bolder NM (1987): Research note: Salmonella decontamination of broiler carcasses with lactic acid, L-cysteine, and hydrogen peroxide. Poult Sci, 66, 1555-1557.

46. No HK, Meyers SP, Prinyawiwatkul W, et al (2007): Applications of chitosan for improvement of quality and shelf life of foods: a review. J Food Sci, 72, 87-100.

47. Okolocha EC, Ellerbroek L (2005): The influence of acid and alkaline treatments on pathogens and the shelf life of poultry meat. Food Control, 16, 217-225.

48. Park SH, Choi MR, Park JW, et al (2011): Use of organic acids to inactivate Escherichia coli O157: H7, Salmonella Typhimurium, and Listeria monocytogenes on organic fresh apples and lettuce. J Food Sci, 76, 293-298.

49. Petracci M, Bianchi M, Mudalal S, et al (2013): Functional ingredients for poultry meat products. Trends Food Sci Technol, 33, 27-39.

50. Rabea EI, Badawy MET, Stevens CV, et al (2003): Chitosan as antimicrobial agent: applications and mode of action. Biomacromolecules, 4, 1457-1465.

51. Rasschaert G, Houf K, De Zutter L (2007): Impact of the slaughter line contamination on the presence of Salmonella on broiler carcasses. J Appl Microbiol, 103, 333-341.

52. Rocha MAM, Coimbra MA, Nunes C (2017): Applications of chitosan and their derivatives in beverages: a critical review. Curr Opin Food Sci, 15, 61-69.

53. Rossler E, Olivero C, Lorena PS, et al (2020): Prevalence, genotypic diversity and detection of virulence genes in 
thermotolerant Campylobacter at different stages of the poultry meat supply chain. Int J Food Microbiol, 326, 108641.

54. Smulders F (1995): Preservation by microbial decontamination; the surface treatment of meats by organic acids. 253-282. In: GW Gould (Ed), New methods of food preservation. Blackie Academic and Professional, London.

55. Sofos JN, Smith GC (1998): Nonacid meat decontamination technologies: model studies and commercial applications. Int J Food Microbiol, 44, 171188.

56. Şenel S, McClure SJ (2004): Potential applications of chitosan in veterinary medicine. Adv Drug Deliv Rev, 56, 1467-1480.

57. Tamblyn KC, Conner DE (1997): Bactericidal activity of organic acids against Salmonella Typhimurium attached to broiler chicken skint. J Food Prot, 60, 629-633.

58. Theron MM, Lues JF (2007): Organic acids and meat preservation: a review. Food Rev Int, 23, 141-158.

59. Trongjit S, Angkititrakul S, Tuttle RE, et al (2017): Prevalence and antimicrobial resistance in Salmonella enterica isolated from broiler chickens, pigs and meat products in Thailand-Cambodia border provinces. Microbiol Immunol, 61, 23-33.

60. Vargas M, González-Martínez C (2010): Recent patents on food applications of chitosan. Recent Pat Food Nutr Agric, 2, 121-128.
61. Wajid M, Awan AB, Saleemi MK, et al (2018): Multiple drug resistance and virulence profiling of Salmonella enterica serovars Typhimurium and Enteritidis from poultry farms of Faisalabad, Pakistan. Microb Drug Resist, 25, 133-143.

62. Witkowska D, Kuncewicz M, Żebrowska JP, et al (2018): Prevalence of Salmonella spp. in broiler chicken flocks in northern Poland in 2014-2016. Ann Agric Environ Med, 25, 693.

63. Xiong H, Li Y, Slavik MF et al (1998): Spraying chicken skin with selected chemicals to reduce attached Salmonella Typhimurium. J Food Prot, 61, 272-275.

64. Yang X, Huang J, Zhang Y, et al (2020): Prevalence, abundance, serovars and antimicrobial resistance of Salmonella isolated from retail raw poultry meat in China. Sci Total Environ, 713, 136385.

65. Yildirim Y, Gonulalan Z, Pamuk S, et al (2011): Incidence and antibiotic resistance of Salmonella spp. on raw chicken carcasses. Food Res Int, 44, 725-728.

66. Zargar V, Asghari M, Dashti A (2015): A review on chitin and chitosan polymers: structure, chemistry, solubility, derivatives, and applications. Chem Bio Eng Reviews, 2, 204-226.

67. Zhao X, Hu M, Zhang Q, et al (2020): Prevalence and antimicrobial resistance of Salmonella isolated from broilers in Shandong, China. Avalaible at: https://doi.org/10.21203/rs.3.rs-17378/v1. (Accessed Sept 24, 2020). 